\title{
Joining of zirconia mechanically metallized with titanium
}

\section{(União de zircônia mecanicamente metalizada com titânio)}

\author{
J.S.Pimenta ${ }^{1}$, A.J.A.Buschinelli ${ }^{1}$, R.M.do Nascimento ${ }^{2}$, A. E. Martinelli ${ }^{2}, J$. Remmel $^{3}$ \\ ${ }^{I}$ Departamento de Engenharia Mecânica, Labsolda, Universidade Federal de Santa Catarina \\ C. P. 476, Campus Trindade, Florianópolis, SC, Brazil 88040-970 \\ ${ }^{2}$ Departamento de Engenharia de Materiais, Universidade Federal do Rio Grande do Norte \\ C. P. 1524, Campus Lagoa Nova, Natal, RN, Brazil 59072-970 \\ ${ }^{3}$ Forschungszentrum Juelich, Zentralabteilung Technologie - ZAT, D 52425 Juelich, Germany \\ jspimenta@emc.ufsc.br
}

\begin{abstract}
Direct brazing is a well-known technique for joining ceramics either themselves or to metals, whereby the required costly active filler alloys are considered a handicap of this process. In this work the indirect brazing of zirconia to zirconia mechanically metallized with $\mathrm{Ti}$ was successfully achieved using conventional filler alloys. The mechanical metallization specially applied to oxide ceramics is a successfully technique that was patented by Forschungszentrum Juelich, Germany, and it has been the subject of applied researches in the last 10 years. This particular metallization is made at room temperature with low cost production and is environmentally safe. Partially stabilized zirconia with yttria was mechanically metallized with Ti and wetting conditions were evaluated using Ag-28Cu and Au-18Ni fillers. These conventional fillers dissolve part of the Ti-coating becoming on-site at brazing temperature an active filler alloy which reacts with the zirconium oxide to improve wetting on the ceramic surface. Better results were selected for brazing tests in a high-vacuum furnace $\left(<3 \times 10^{-5} \mathrm{mbar}\right)$. Helium gas leak detection was made at the ceramic/ ceramic interface at room temperature; samples from reliable vacuum tight joints were examined by microestructural analysis and linescan technique by energy dispersive X-ray analysis in its cross-section. Microhardness profiles were made across the joint interface where zirconia undergone darkening after brazing process. Sound brazed joints were produced even when just one ceramic surface of the joint assemble was previously metallized, due to titanium diffusion from the metallized ceramic surface to the other ceramic side at the joint assemble.
\end{abstract}

Keywords: mechanical metallization, zirconia, Ti-coating, brazing.

Resumo

A brasagem direta é uma técnica bem conhecida para união de cerâmicas entre si bem como aos metais, segundo a qual as ligas de adição requeridas são consideradas uma relativa desvantagem devido ao aumento nos custos do processo. Neste trabalho, a brasagem indireta da zircônia à zircônia mecanicamente metalizada com Ti foi alcançada com sucesso, usando-se ligas de adição convencionais. A metalização mecânica especialmente aplicada aos óxidos cerâmicos é uma técnica bem sucedida que foi patenteada pelo Forschungszentrum Juelich, Alemanha, e tem sido tema de pesquisas nos últimos 10 anos. Esta metalização particular é feita à temperatura ambiente com baixo custo de produção, sendo ambientalmente segura. Zircônia parcialmente estabilizada com ítria (Y-PSZ) foi mecanicamente metalizada com Ti e as condições de molhamento foram avaliadas usando as ligas de adição Ag-28Cu e Au-18Ni. Estas ligas de adição convencionais dissolvem parte do revestimento de titânio, tornando-se ligas ativas na temperatura de brasagem para reagir com o óxido de zircônio e acentuar o molhamento na superfície cerâmica. Os melhores resultados foram selecionados para os testes de brasagem em forno de alto-vácuo $\left(<3 \times 10^{-5}\right.$ mbar $)$. A detecção de vazamento de gás hélio foi efetuada na interface cerâmica/cerâmica à temperatura ambiente; amostras de juntas estanques confiáveis foram examinadas por análise microestrutural e pela técnica linescan através de análise por difração de raios X na seção transversal das mesmas. Perfis de microdureza foram feitos através da interface da junta onde zircônia passou por efeito de escurecimento durante o processo de brasagem. Juntas brasadas de boa qualidade foram produzidas quando apenas uma das superfícies cerâmicas em contato foi previamente metalizada, devido à difusão de titânio desta superfície para a outra face cerâmica não-metalizada.

Palavras-chave: metalização mecânica, zircônia, revestimento de titânio, brasagem.

\section{INTRODUCTION}

Advanced ceramics include oxides, carbides, nitrides and a number of their composites that usually have high corrosion and oxidation strength at elevated temperatures, high abrasion strength and good mechanical properties. However, these materials are expensive, brittle and exhibit poor machinability to be difficult to fabricate into large or complex shaped components [1-2]. Brazing is a flexible and well-documented process to overcome these drawbacks 
and produce hybrid components with reliable interfaces and improved engineering properties [3-5].

Active metal brazing is the most common method for joining ceramics to either themselves or to metals in which is used a filler alloy that contain low percents of an active metal in its composition, such as $\mathrm{V}, \mathrm{Cr}, \mathrm{Ta}, \mathrm{Hf}, \mathrm{Zr}$ and specially $\mathrm{Ti}$ (commercially 1.5-4.5 wt.\%). These solutes promote lower contact angles and enhance the ceramic/metal wettability by the melted filler alloy reducing the oxide that constitutes the main ceramic phase. Formation of a continuous interfacial reaction layer between the ceramic and filler is crucial for joint strength [6-8]. However, excessive reduction reactions can produce a reaction layer with undesirable intermetallic phases decreasing mechanical properties of the brazing joint. Moreover, higher costs of these fillers has driven forward alternative joining approaches such as previous metallization on the ceramic surface with an active metal and subsequent indirect brazing process using active-metal free filler alloys [9-11].

Several techniques have been documented for ceramic metallization in the scientific literature, such as plasma spray, physical and chemical vapour deposition (PVD and CVD process, respectively). Nevertheless they have the handicap of being more expensive and laborious than the here proposed mechanical metallization. By the other side, the well-known Mo-Mn process is inappropriate for zirconia metallization because it does not have a glassy intergranular phase, which is a key factor for joining between the formed metallic film and ceramic substrate $[3$, 12]. The mechanical metallization technique was patented by Forschungszentrum Juelich (Germany) and it has been in continuous development, involving studies about oxide and non-oxide ceramics to produce vacuum tight ceramic/ metal joints with good mechanical strength and low cost production $[10,11]$. It has been successfully applied at laboratory scale using commercially pure $\mathrm{Ti}$ tools to make an active metal coating on the ceramic surface. It have been noticed that typical microstructure at the ceramic/metal interface is characterized by eutectic constituent closely to a rich-Ti reaction layer and eventually by a precipitation zone between them, which contains dispersive intermetallic phases [9].

Zirconia ceramic exhibits three well-defined polymorphs: monoclinic $\left(\mathrm{m}-\mathrm{ZrO}_{2}\right)$ at room temperature and pressure; tetragonal $\left(\mathrm{t}-\mathrm{ZrO}_{2}\right)$ increasing temperature above $\approx 1170{ }^{\circ} \mathrm{C}$; and then to a cubic structure $\left(\mathrm{c}-\mathrm{ZrO}_{2}\right)$ starting about $2360{ }^{\circ} \mathrm{C}$ with melting temperature $\approx 2716^{\circ} \mathrm{C}[3,13]$. A suitable tetragonal-monoclinic $(\mathrm{t} \rightarrow \mathrm{m})$ transformation is important to promote high abrasion strength associated to better mechanical properties. However, additions of certain metal oxides such as calcia $(\mathrm{CaO})$, ceria $\left(\mathrm{CeO}_{2}\right)$, magnesia $(\mathrm{MgO})$ or yttria (usually $3.0-4.5 \mathrm{~mol} \%$ or $\approx 6-8 \mathrm{wt} . \% \mathrm{Y}_{2} \mathrm{O}_{3}$ ) plus a controlled heat treatment are crucial to overcome the volume increase (3-5\%) typical in pure zirconia caused by $\mathrm{t} \rightarrow \mathrm{m}$ transformation, which is known to be similar to that of martensite formation when quenching steel $[13,14]$. The stresses induced are sufficient to produce a spontaneous cracking in pure zirconia on cooling from its firing temperature.

Commercial forms of transformation-toughened zirconia are: partially stabilized zirconia (PSZ; e.g. Ca-PSZ, Mg- PSZ, Y-PSZ) with lenticular tetragonal precipitates - lens shaped - in a cubic matrix; and tetragonal zirconiapolycristals (TZP; e.g. Y-TZP, Ce-TZP) nominally $\approx 98 \%$ tetragonal with fine grain size $<0.5 \mu \mathrm{m})[13,14]$. Properties like high corrosion and oxidation strength at elevated temperatures and higher mechanical strength and fracture toughness comparing to other dense ceramics particularly at temperatures below $\approx 300{ }^{\circ} \mathrm{C}$ for $\mathrm{KIC}$ values in the range $15-20 \mathrm{MPa} \cdot \mathrm{m}^{1 / 2}$ are beneficial in a large technical applications range from wire drawing dies, cutting and machining tools, gas turbines to oxygen sensors and solid oxide fuel cells (SOFCs) [1, 3, 4, $15]$.

In the present study, titanium was mechanically deposited on the ceramic surface as a previous stage for brazing zirconia to zirconia using two commercial active-metalfree filler alloys. The objectives were producing reliable vacuum tight brazing joints, based on previous knowledge about wetting behavior on the metallized ceramic surface, characterizing the resultant microstructure at the joint interface and evaluating how the darkening effect in zirconia affects the joining quality.

\section{EXPERIMENTAL PROCEDURES}

Ceramic material rods $\varnothing 8.0 \mathrm{~mm}$ are yttria partially stabilized zirconia (Y-PSZ, $\approx 8.5$ wt. $\% \mathrm{Y}_{2} \mathrm{O}_{3}$ ) produced by Friatec, Germany, whose properties are shown in Table I. The conical-shape tools used for mechanical metallization were produced from a rod of commercially pure Ti (ASTM

Table I - Physical and mechanical properties of the zirconia ceramic (Degussit FZY*) used in the study. [Tabela I - Propriedades físicas e mecânicas da zircônia (Degussit FZY*) usada no estudo.]

\begin{tabular}{cccccccc}
\hline $\begin{array}{c}\text { Composition } \\
(\text { wt. } \%)\end{array}$ & $\begin{array}{c}\text { Apparent } \\
\text { density, } \\
20{ }^{\circ} \mathrm{C}\left(\mathrm{g} / \mathrm{cm}^{3}\right)\end{array}$ & $\begin{array}{c}\text { Open } \\
\text { porosity } \\
(\%)\end{array}$ & $\begin{array}{c}\text { Knoop } \\
\text { hardness } \\
(100 \mathrm{~g})\end{array}$ & $\begin{array}{c}\text { Bending } \\
\text { strength } \\
(\mathrm{MPa})\end{array}$ & $\begin{array}{c}\mathrm{E} \text { modulus } \\
(\mathrm{GPa})\end{array}$ & $\begin{array}{c}\text { Maximum } \\
\text { operating } \\
\text { temperature }\left({ }^{\circ} \mathrm{C}\right)\end{array}$ & $\begin{array}{c}\mathrm{CTE} \\
\left(10^{-6}{ }^{\circ} \mathrm{C}^{-1}\right)\end{array}$ \\
\hline $\begin{array}{c}8.5 \% \mathrm{Y}_{2} \mathrm{O}_{3}, \\
\mathrm{ZrO}_{2} \text { balance }\end{array}$ & $5.50-5.80$ & 0 & 17,000 & 400 & 200 & 1500 & $\left(20-1000{ }^{\circ} \mathrm{C}\right)$ \\
\hline
\end{tabular}


grade 2). Commercial filler alloys with $50 \mu \mathrm{m}$ thickness were VH780 (Ag-28Cu) and VH950 (Au-18Ni), respectively for working temperatures in the range $780-820{ }^{\circ} \mathrm{C}$ and $970{ }^{\circ} \mathrm{C}$, according to the manufacturer (Umicore AG \& Co. KG).

An obvious consideration about the filler alloy is that it must have its liquidus temperature higher than provided work temperature of brazed joint, but lower than component's melting temperature. The eutectic $\mathrm{Ag}-\mathrm{Cu}$ based filler is generally preferred for ceramic/ ceramic or ceramic/metal joining because it is ductile and chemically inert, what reduces oxidation and therefore minimizes residual stresses during cooling from brazing temperature [4, 15]. In relation to the $\mathrm{Au}-18 \mathrm{Ni}$ filler, gold has excellent thermal conductivity $(315 \mathrm{~W} / \mathrm{m} . \mathrm{K})$ and resistance to oxidation, including very high ductility that is also beneficial to the accommodation of the thermal stresses via interfacial plastic flow [6].

Before metallization, the ceramic samples were polished to $6 \mu \mathrm{m}$ diamond suspension and ultrasonically cleaned in acetone bath for $10 \mathrm{~min}$. Afterwards, samples were attached to the lathe and turned on the counterclockwise under constant speed (800 rpm), while the conical-shape tool was attached to a reworking high speed that turned on the clockwise $(27,000 \mathrm{rpm})$, according to the scheme in Fig. 1. During the contact between these parts, the metallic tool wore out and titanium was deposited on the ceramic surface. Parameters used for metallization process were selected from the previous studies; oxidation behavior was not detected under these conditions $[9,10]$.

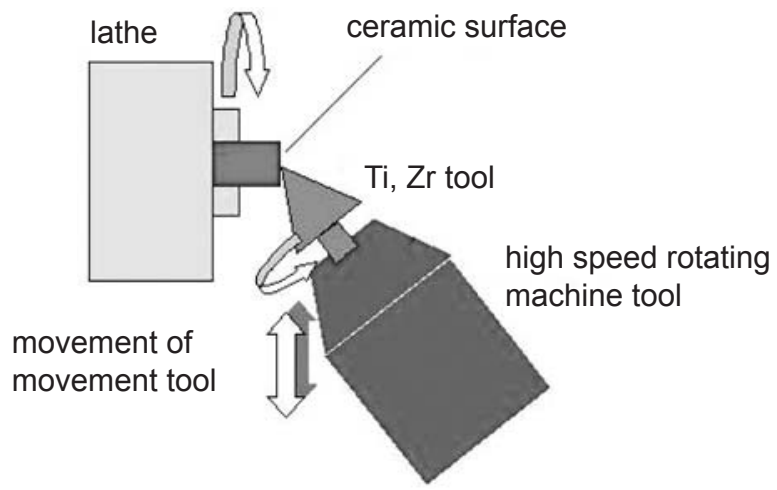

Figure 1: Schematic illustration of the mechanical metallization technique (Ref. 9, adapted).

[Figura 1: Ilustração esquemática da técnica de metalização mecânica (Ref. 9, adaptado).]

Wetting tests were made in a high-vacuum furnace at FZJuelich (Pfeiffer MOV262) in zirconia samples mechanically metallized with Ti using both filler alloys for two thermal cycles for each one. Wetting temperatures tested for the respective fillers were $820{ }^{\circ} \mathrm{C}$ and $880{ }^{\circ} \mathrm{C}$ for $\mathrm{Ag}-28 \mathrm{Cu}$ filler, $980{ }^{\circ} \mathrm{C}$ and $1050{ }^{\circ} \mathrm{C}$ for $\mathrm{Au}-18 \mathrm{Ni}$ filler. Generally, these temperatures for experimental activities are at least $30-50{ }^{\circ} \mathrm{C}$ over the liquidus of the fillers [3].

Standard thermal cycle used for both wetting and brazing tests is shown in Fig. 2. There are two levels for temperature homogenization at $700{ }^{\circ} \mathrm{C}$ and $750{ }^{\circ} \mathrm{C}$ and the third level is specified for wetting and subsequent brazing temperature

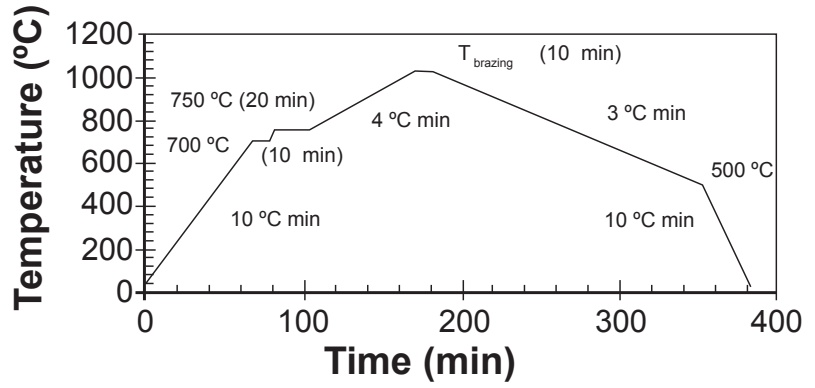

Figure 2: Standard thermal cycle used for wetting and brazing tests.

[Figura 2: Ciclo térmico padrão usado para os testes de molhamento e brasagem.]

(soaking for $10 \mathrm{~min}$ ), depending on the filler alloy.

Contact angles were measured when samples were first removed from the vacuum furnace in the end of wetting tests by software developed at UFRN using images analysis. Wetting conditions were also qualitatively analyzed by visual inspection and microestructural analysis techniques at the ceramic/ filler interface to determine better conditions for subsequent brazing tests.

Each joint assemble was submitted by a pressure on its top approximately $120 \mathrm{kPa}$ and fixed to avoid misalignments. Mechanical loads should be applied to improve brazing alloys spreading on the ceramic surface at brazing temperatures, but this limits the application fields in industrial products with complicated shape [1]. Brazing zirconia to zirconia was made in a high-
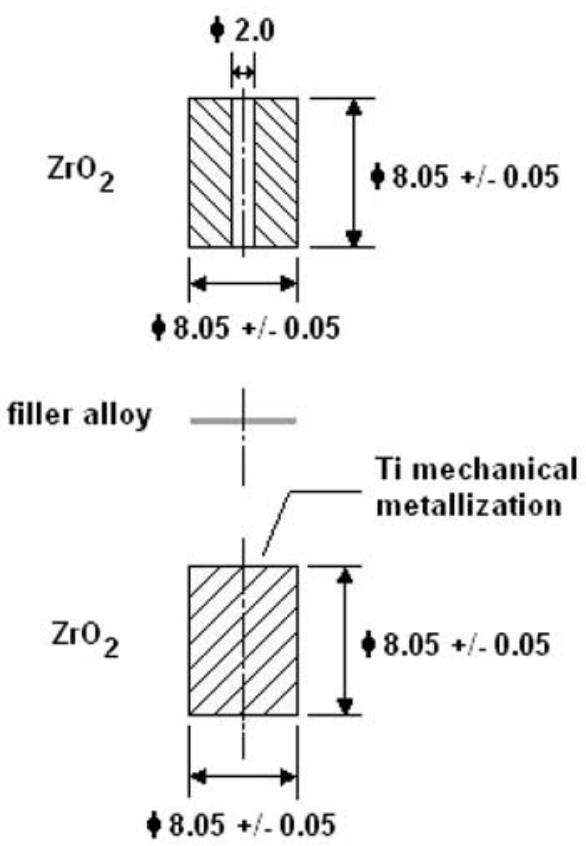

Figure 3: Joints configuration used for brazing and He gas leak tests (dimension in $\mathrm{mm}$ ).

[Figura 3: Configuração das juntas para os testes de brasagem e detecção de vazamento de gás He (dimensão em $\mathrm{mm}$ ).] 
vacuum furnace (better $3 \times 10^{-5}$ mbar) using a simple buttjoint configuration, which was also useful for He gas leak tests at room temperature in accordance to the Standard DIN EN 1779 (Inficon UL200 equipment) - see scheme in Fig. 3.

Samples were selected from tight brazing joints and its cross-section examined for microestructural analysis: mounted in epoxy and cut on a low-speed diamond wire, grinded using diamond grinding paper (76 $\mu \mathrm{m}, 40 \mu \mathrm{m}, 20 \mu \mathrm{m}, 10 \mu \mathrm{m})$, polished on diamond suspension $(6 \mu \mathrm{m}, 3 \mu \mathrm{m}, 1 \mu \mathrm{m})$ and submitted to final polish using $0.025 \mu \mathrm{m} \mathrm{SiO}_{2}$ colloidal silica polishing suspension. Cross-section at the joints interface was analyzed by optical and scanning electron microscopy (SEM) using back-scattered electron image (BEI) - Shimadzu SSX550 equipped with linescan technique by energy dispersive $\mathrm{X}$-ray analysis (EDX), operating voltage of $20 \mathrm{kV}$ at CTGAS (Natal, RN). Microhardness measurements were made using Vickers micro-indenter on a Shimadzu HMV-2 machine (load of $200 \mathrm{~g}$ for $10 \mathrm{~s})$.

\section{RESULTS AND DISCUSSION}

Wettability of the metallized ceramic surface by melted filler alloy is a key factor for brazing either ceramic to ceramic or ceramic to metals. In fact, the joining just will happen if the active metal from the filler superficially reacts with ceramic substrate to improve wetting on it, producing new phases and the formation of a resultant interface with reliable vacuum tightness and good mechanical strength. Suitable microstructure at the interface is also essential to obtain sound brazed joints, since that excessive growing of the reaction layer and precipitation zone will promote its embrittlement [9]. Moreover, the new component would be less able to support residual stresses produced during cooling from brazing temperature. Wetting behavior and resultant microstructure analysis at the interface are crucial for development of a joining process that involves a liquid phase.

\section{Wettability and brazing condition}

Results of wetting tests are shown in Table II, including the conditions selected for brazing tests at $820{ }^{\circ} \mathrm{C}$ and $980{ }^{\circ} \mathrm{C}$ for the $\mathrm{Ag}-28 \mathrm{Cu}$ and $\mathrm{Au}-18 \mathrm{Ni}$ filler, respectively. Mechanical metallization with Ti was efficient to obtain very good wetting conditions using the eutectic Ag-28Cu filler; however results for the $\mathrm{Au}-28 \mathrm{Ni}$ filler were not so satisfactory - wetting condition occurred but with insufficient spreading on the metalized surface. Although wetting results had not been so favorable using $\mathrm{Au}-18 \mathrm{Ni}$ filler (see partial wetting at $980{ }^{\circ} \mathrm{C}$ ), this condition was also selected for subsequent brazing tests. There was no adherence by the melted Au$18 \mathrm{Ni}$ filler at $1050{ }^{\circ} \mathrm{C}$ on the metalized ceramic surface.

Fig. 4 shows representative wetting tests for both investigated filler alloys. Contact angle measurements were not made for tests using the Ag-28Cu filler because there was total wetting and spreading on the metalized ceramic surface for both wetting temperatures (see Fig. 4a). Results for melted Au-18Ni filler were not satisfactory
Table II - Summarized results of wetting tests in Y-PSZ ceramic metalized with $\mathrm{Ti}$ and selected conditions for brazing temperature (in bold).

[Tabela II - Resultados resumidos dos testes de molhamento na cerâmica Y-PSZ metalizada com Ti e condições selecionadas para temperatura de brasagem (em negrito).]

\begin{tabular}{|c|c|c|c|c|}
\hline \multirow{5}{*}{$\begin{array}{l}\text { Wetting } \\
\text { condition }\end{array}$} & \multicolumn{4}{|c|}{ Filler alloy } \\
\hline & \multicolumn{2}{|c|}{ VH780 (Ag-28Cu) } & \multicolumn{2}{|c|}{ VH950 (Au-18Ni) } \\
\hline & \multicolumn{4}{|c|}{ Wetting temperature, soaking $10 \mathrm{~min}$} \\
\hline & $820^{\circ} \mathrm{C}$ & $880^{\circ} \mathrm{C}$ & $980^{\circ} \mathrm{C}$ & $1050^{\circ} \mathrm{C}$ \\
\hline & wetting & wetting & $\begin{array}{c}\text { partial } \\
\text { wetting }\end{array}$ & $\begin{array}{c}\text { No } \\
\text { adherence }\end{array}$ \\
\hline
\end{tabular}

(a) Partial means that contact angle $<90^{\circ}$ but insufficient spreading on the ceramic surface.
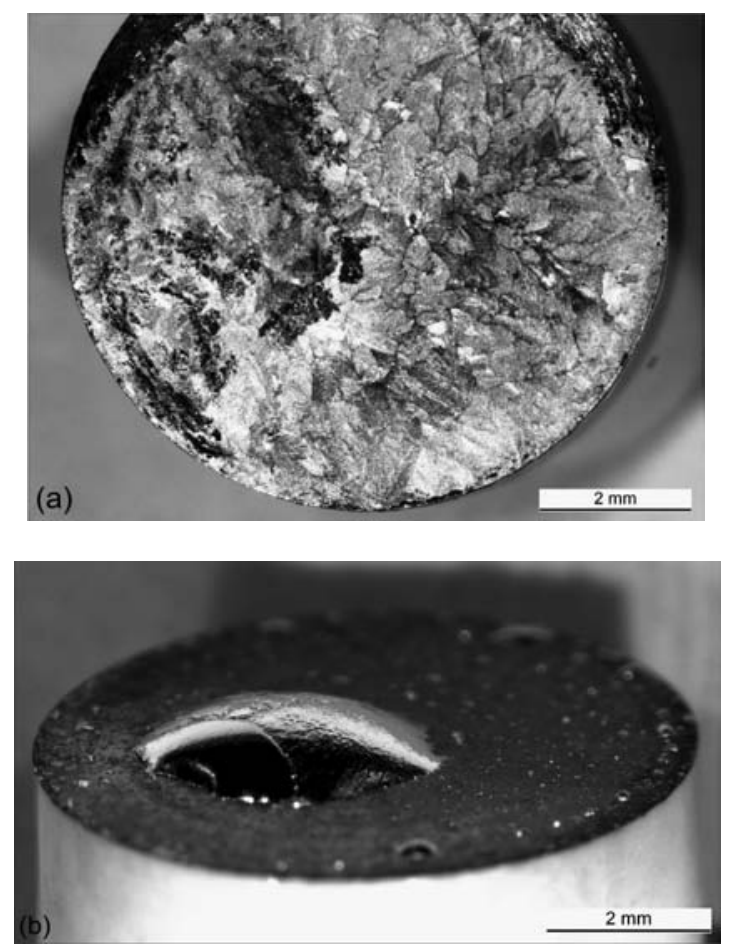

Figure 4: (a) Excellent wetting condition using $\mathrm{Ag}-28 \mathrm{Cu}$ filler at $820^{\circ} \mathrm{C}$ (top view); (b) Partial wetting using Au-18Ni filler at $980{ }^{\circ} \mathrm{C}$ : poor spreading of the melted filler alloy on the ceramic surface.

[Figura 4: (a) Condição de molhamento excelente com a liga de adição Ag-28Cu a $820{ }^{\circ} \mathrm{C}$ (vista superior); (b) Molhamento parcial com a liga Au-18Ni a $980^{\circ} \mathrm{C}$ : espalhamento pobre da liga fundida sobre a superfície cerâmica.]

because wetting occurred (contact angle, $\theta<90^{\circ}$ ) but there was poor spreading on the ceramic surface (see Fig. 4b). Contact angles were measured when samples were removed from the vacuum furnace. These measurements for the $\mathrm{Au}-18 \mathrm{Ni}$ filler are in the range $35^{\circ}-40^{\circ}$ for tests at $980{ }^{\circ} \mathrm{C}$. There was not adherence on the substrate using these filler for tests at $1050{ }^{\circ} \mathrm{C}$. For practical purposes contact angle 
values between $70^{\circ}-90^{\circ}$ may be insufficient to provide satisfactory spreading on the ceramic surface $[9,16]$.

\section{Tightness of the brazed joints}

Table III shows the summarized results of leak test for investigated ceramic/ceramic joints. Leak rateswere considered very satisfactory with values bellow $10^{-9} \mathrm{mbar} . \mathrm{l} . \mathrm{s}^{-1}$ for both Y-PSZ/Ag-28Cu/Y-PSZ and Y-PSZ/Au- 18Ni/Y-PSZ brazing joints. Titanium coating deposited by mechanical metallization was efficient for the joining process. Reliable vacuum tight joints were selected for microstructural analysis at the resultant interface.

Table III - Summarized results of the He gas leak tests for brazed joints.

[Tabela III - Resultados dos testes estanqueidade com gás He para as juntas brasadas.]

\begin{tabular}{ccc}
\hline \multicolumn{3}{c}{ Brazing temperature: $820^{\circ} \mathrm{C}, 10 \mathrm{~min}$} \\
VH780 (Ag-28Cu)
\end{tabular}

Schröder et al [17] suggested that the allowable maximum leak rate for most cases of technical application is in the range $10^{-6}-10^{-8}$ mbar.l. $\mathrm{s}^{-1}$. These researchers consider that leak values bellow $10^{-8}$ mbar.l. $\mathrm{s}^{-1}$ allow to classify vacuum tight components, which means that there would be approximately $3 \mathrm{ml}$ of helium gas loss in 1 year in the presence of a discontinuity with diameter $\approx 0,4 \mu \mathrm{m}$. They also suggested that only extremely low leak rates $\left(<10^{-10}\right.$ mbar. $\left.\ell . \mathrm{s}^{-1}\right)$ can classify technically vacuum tight components.

\section{Darkening effect in zirconia}

Fig. 5 shows the darkening in zirconia next to the brazed joint interface. Tests made with the Au-18Ni filler exhibited a longer dark area at the joint interface than tests using the $\mathrm{Ag}-28 \mathrm{Cu}$ filler (see Fig. 5a). In fact, brazing temperature for the former filler was higher than that to the eutectic $\mathrm{Ag}-\mathrm{Cu}$ filler $-980{ }^{\circ} \mathrm{C}$ and $820^{\circ} \mathrm{C}$, respectively.

Titanium coating was deposited on the ceramic surface using approximately the same conditions because of the specificity of this metallization process; and soaking time for $10 \mathrm{~min}$ at the brazing temperature was maintained in all tests. Thus, it was noticed that the brazing temperature had influence in the darkening effect extension in zirconia ceramic. Fig. 5b exhibits cross-section of the ceramic/ ceramic joints that were initially submitted to brazing tests to verify its real possibility of joining. In addition, the titanium deposition occurred on the ceramic surface that exhibited longer dark area extension from its brazed joint interface.

Researchers have reported this typical darkening effect in zirconia at the joint interface after active brazing using filler alloys containing $\mathrm{Ti}$ as active metal $[2,5,6]$. This phenomenon can be attributed to a partial scavenging of oxygen ions from the ceramic by titanium cations leading to O-deficient darkened region in zirconia [5, 15]. In other words, there is formation of a non-stoichiometric zirconia caused by an active metal with high affinity for oxygen according to the following equation [3]:

$$
\mathrm{ZrO}_{2} \rightarrow \mathrm{ZrO}_{2-\mathrm{X}}+\mathrm{X} / 2 \mathrm{O}_{2} \text {, where } 0<\mathrm{X} \leq 0,02
$$

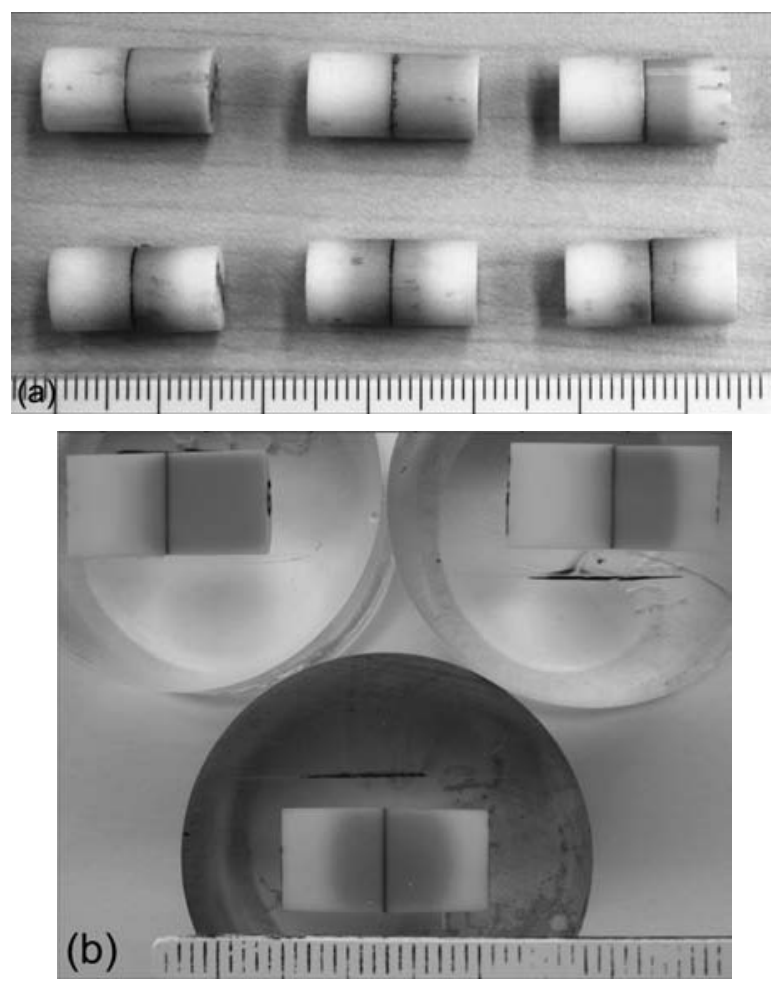

Figure 5: Darkening effect in zirconia: (a) Y-PSZ/Au-18Ni/Y-PSZ joints on top (brazing at $980^{\circ} \mathrm{C}$ ) and Y-PSZ/Ag- $28 \mathrm{Cu} / \mathrm{Y}$-PSZ joints on bottom (brazing at $820^{\circ} \mathrm{C}$ ); (b) Samples cross-section.

[Figura 5: Efeito de escurecimento na zircônia: (a) juntas Y-PSZ/ Au-18Ni/Y-PSZ acima (brasagem a $980{ }^{\circ} \mathrm{C}$ ) e juntas Y-PSZ/Ag$28 \mathrm{Cu} / \mathrm{Y}$-PSZ abaixo (brasagem a $820{ }^{\circ} \mathrm{C}$ ); (b) Seção transversal das amostras.]

The darkening effect in zirconia can be also influenced by some factors, such as dwell time at brazing temperature, the substrate to which zirconia is being joined, and the percentage of active metal in the filler alloy composition (especially Ti). Moreover, it was proposed that the brazed joint strength and this $\mathrm{O}$ deficient dark area in zirconia are independent of each other [3]. 


\section{Microhardness measurements}

Vickers microhardness profiles across the examined ceramic/ceramic interfaces are shown in Fig. 6. Indentations were first performed on zirconia about $50 \mu \mathrm{m}$ far from the interface. It was noticed that hardness is slightly higher inside of the thin braze region for the $\mathrm{Au}-18 \mathrm{Ni}$ filler than the $\mathrm{Ag}-28 \mathrm{Cu}$ filler. Hardness rises rapidly upon entering in ceramic region, which leads to a sharp discontinuity in the microhardness profile at the joint interface. Microhardness measurements from closely to braze region into the depth of zirconia revealed that besides of its typical darkening effect (see previous Fig. 5) there was no remarkable negative influence in this mechanical property.

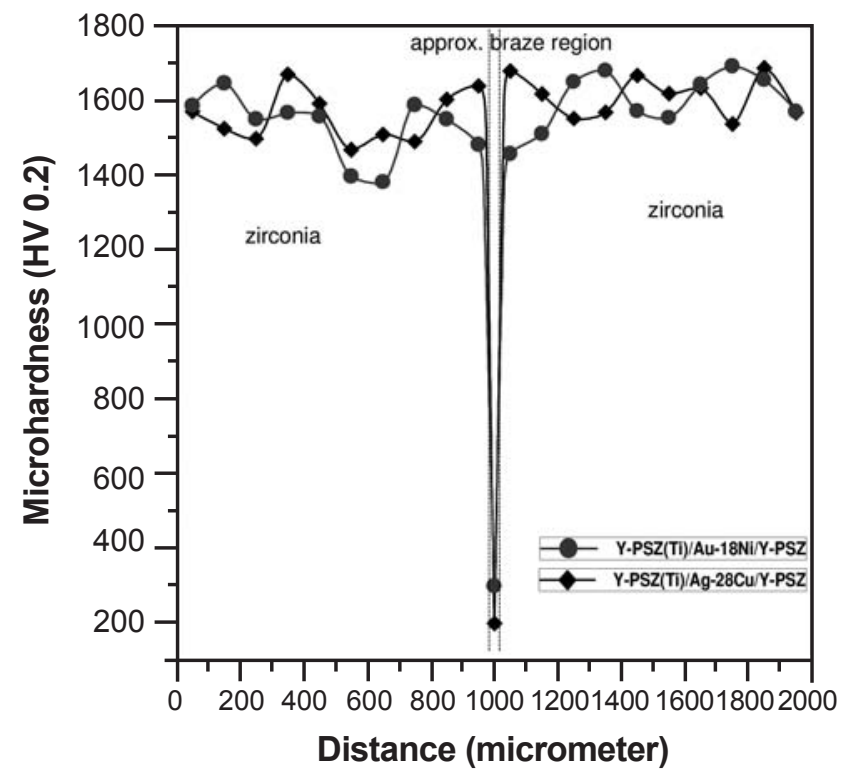

Figure 6: Microhardness profiles across the brazed joint interface, (Ti) means metallization with titanium.

[Figura 6: Perfil de microdureza através da interface da junta brasada, (Ti) significa metalização com titânio.]

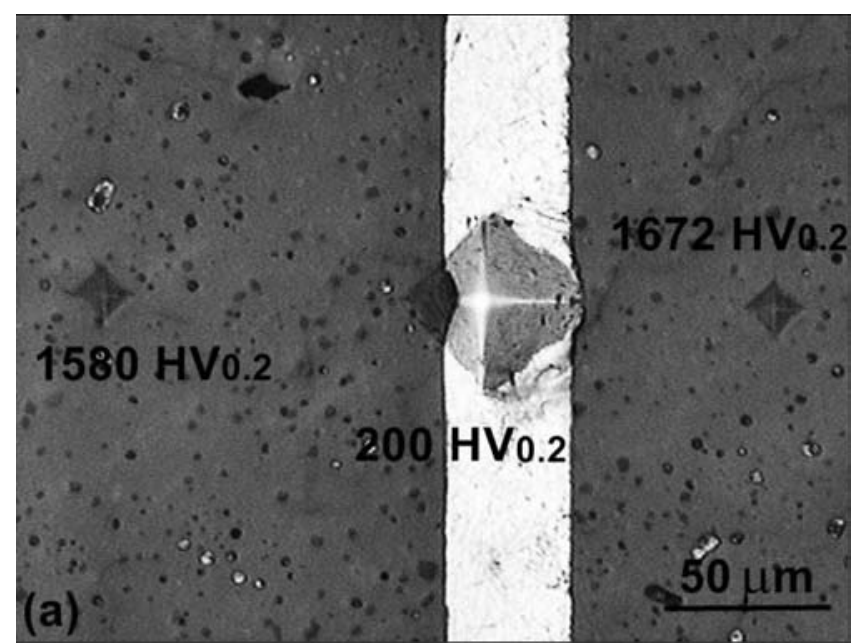

Fig. 7 shows optical images with microhardness indentation at the brazed joints interface. In these samples, braze region for the $\mathrm{Ag}-28 \mathrm{Cu}$ filler is less thick than region with Au-18Ni fileer (see Fig. 7a). A precipitation zone was formed at the braze region when used the Au18Ni filler, probably next to the ceramic surface where there was titanium deposition (at left side, Fig. 7b).

In addition, residual thermal stresses due to the mismatch among the linear thermal expansion coefficient $(\alpha-\mathrm{CTE})$ of the individual components should be also considered. Comparatively, the $\alpha$-CTE of zirconia ceramic is $11.2 \times 10^{-6} \mathrm{C}^{-1}$ and fillers $\alpha$-CTE are rather high: $17.8 \times 10^{-6}{ }^{\circ} \mathrm{C}^{-1}$ for the $\mathrm{Ag}$ $28 \mathrm{Cu}$ filler in the range $20-400{ }^{\circ} \mathrm{C}$ and $14.6 \times 10^{-6}{ }^{\circ} \mathrm{C}^{-1}$ for Au-18Ni filler at $20-550{ }^{\circ} \mathrm{C}$. According to these data, it is believed that residual stresses can be accommodate by plastic flow from the large ductility of these fillers during cooling from the brazing temperature $[4,8,15]$.

\section{Microestructural analysis}

Fig. 8 suggests formation of a sound Y-PSZ/Ag-28Cu/YPSZ joint for brazing tests at $820{ }^{\circ} \mathrm{C}$. Optical micrograph in Fig. 8a exhibits a kind of reaction layer closely to the ceramic surface in side A; however it is not exactly a reaction layer as we can see the SEM image in Fig. 8b. It was noticed even with higher magnitude that microstructure in the braze region and closely to the both ceramic/filler interfaces is homogenous and entirely composed by a eutectic Ag$\mathrm{Cu}$ constituent. Moreover, Fig. 8b exhibits a continuous dark reaction layer in both ceramic/filler interfaces which is basically composed by $\mathrm{Ti}-\mathrm{O}$ compounds $\left(\mathrm{TiO}, \mathrm{Ti}_{2} \mathrm{O}_{3}\right.$, $\mathrm{Ti}_{3} \mathrm{O}_{5} \ldots \mathrm{TiO}_{2}$ ) from superficial reduction of zirconium oxide. It is beneficial to improve wetting and spreading on the ceramic substrate by the melted filler alloy and precipitation of active metal oxide [3, 4, 8, 15].

A specific region in side $\mathrm{A}$ at the ceramic/filler interface

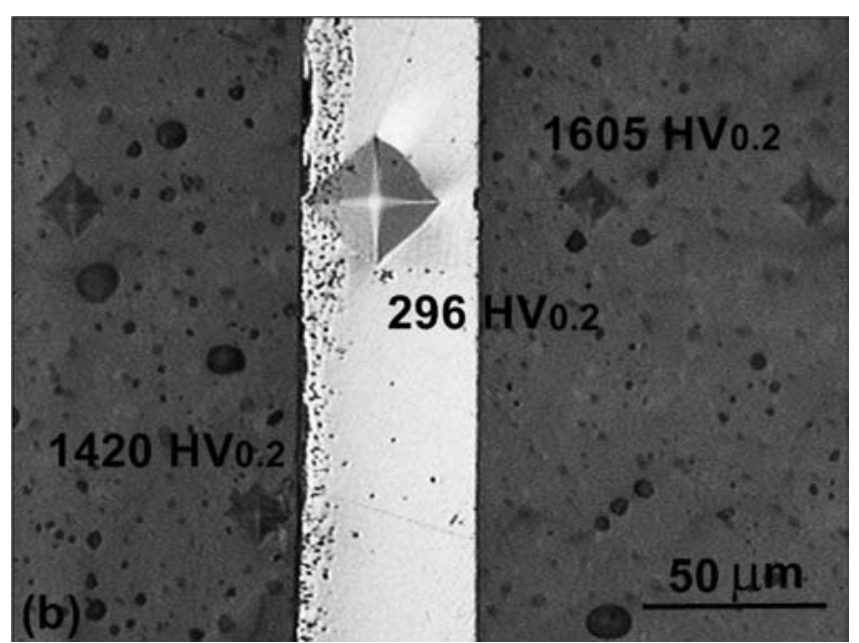

Figure 7: Microhardness indentation $\left(\mathrm{HV}_{0.2}\right)$ across the joint interface: (a) Y-PSZ(Ti)/Ag-28Cu/Y-PSZ, brazing at $820{ }^{\circ} \mathrm{C}$; (b) Y-PSZ(Ti)/ Au-18Ni/Y-PSZ, brazing at $980^{\circ} \mathrm{C}$.

[Figura 7: Indentação de microdureza $\left(H V_{0.2}\right)$ na interface das juntas: (a) Y-PSZ(Ti)/Ag-28Cu/Y-PSZ, brasagem a 820 ${ }^{\circ} \mathrm{C}$; (b) Y-PSZ(Ti)/ $\mathrm{Au}-18 \mathrm{Ni} / \mathrm{Y}$-PSZ, brasagem a $980^{\circ} \mathrm{C}$.] 

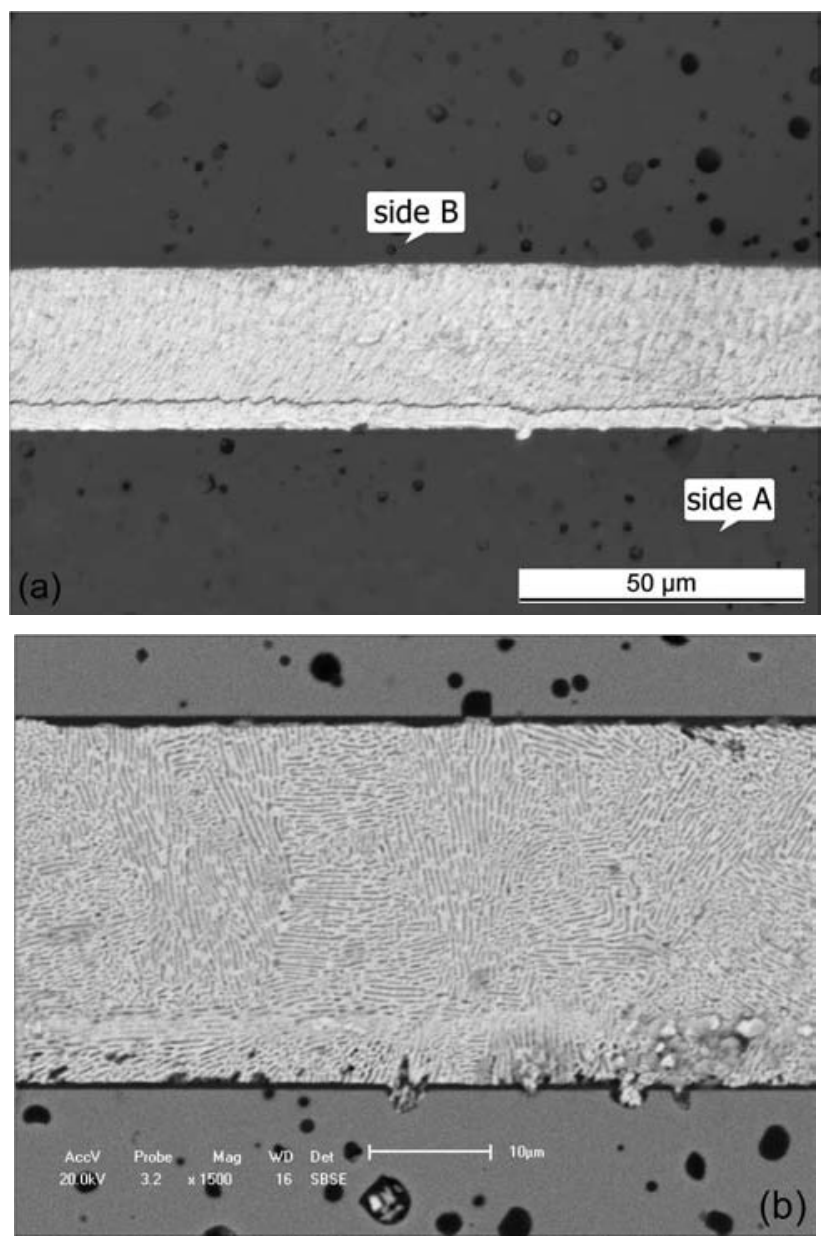

Figure 8: (a) Optical micrograph of Y-PSZ/Ag-28Cu/Y-PSZ; (b) SEM image keeping the same sides $\mathrm{A}$ and $\mathrm{B}$ viewed in (a), homogenous microstructure composed by the eutectic $\mathrm{Ag}-\mathrm{Cu}$ in the braze region.

[Figura 8: (a) Micrografia óptica na interface da junta Y-PSZ/Ag28Cu/Y-PSZ; (b) Imagem eletrônica mantendo os mesmos lados A e $B$ vistos em (a), microestrutura homogênea composta pelo eutético Ag-Cu na região de brasagem.]

from Fig. $8 b$ is shown with higher magnitude in Fig. 9. Microstructure closely to the ceramic surface is quite similar to the bulk of braze region; however here is a slightly Cudeficient region parallel to the interface where lamellar $\mathrm{Cu}$ constituent is lighter than other surround regions (see Fig. 9a). Elemental qualitative analysis by linescan technique is shown in Fig. 9b, in which indicates mechanical metallization with Ti was made in side A of the ceramic substrate (see higher EDX peaks of $\mathrm{Ti}$ at the interface). There was really titanium diffusion from the metallized ceramic surface across the bulk of the melted filler alloy to the other ceramic side in contact.

Fig. 10 also suggests formation of sound Y-PSZ/Au$18 \mathrm{Ni} / \mathrm{Y}-\mathrm{PSZ}$ joints for brazing tests at $980{ }^{\circ} \mathrm{C}$. Similarly to the optical micrograph in Fig. 8a it was produced a kind of reaction layer closely to the ceramic surface (see side B in Fig. 10a). According to the image in Fig. 10b it is not exactly a reaction layer because microstructure is also quite similar to the bulk of braze region. Even though intermetallic phases
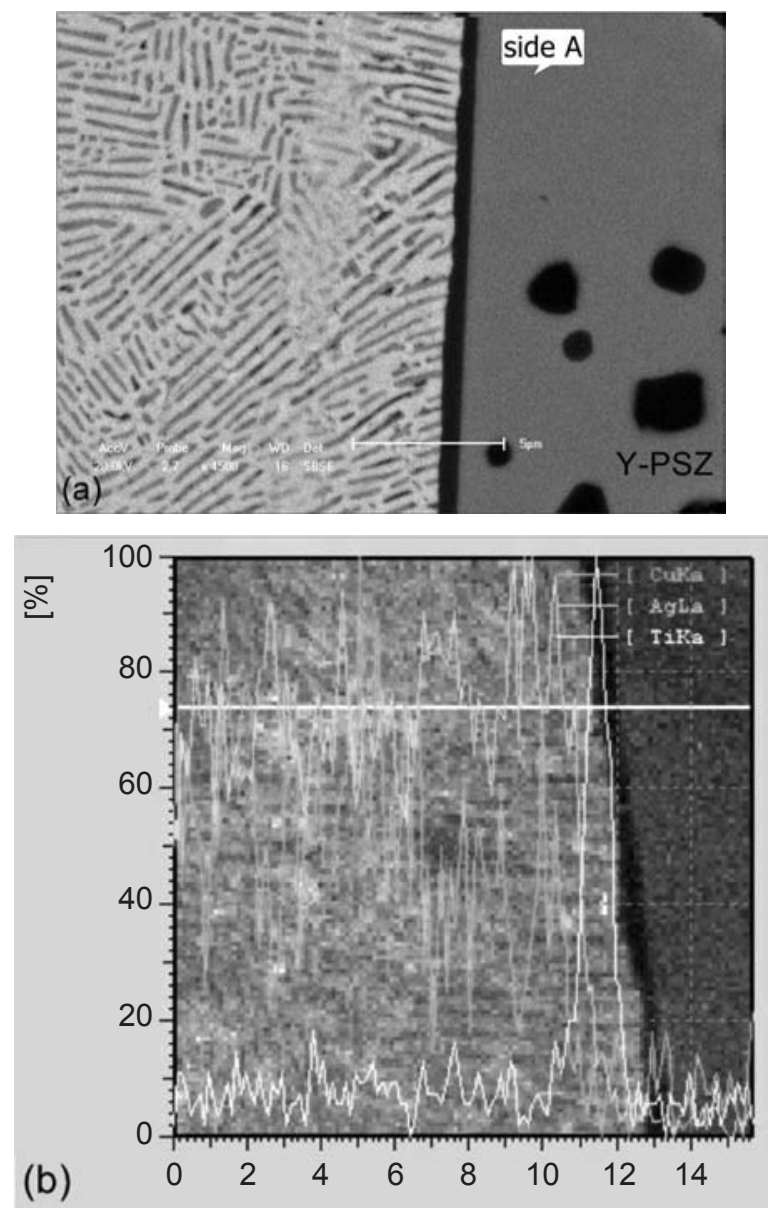

Figure 9: (a) Side A viewed in Fig. 6b showing a continuous dark reaction layer closely to the interface; (b) Linescan technique across the region shown in (a), metallization zone with $\mathrm{Ti}$ at the interface in side A.

[Figura 9: (a) Lado A visto na Fig. 6 b mostrando uma contínua camada de reação escura próxima à interface da junta; (b) Técnica linescan através da região mostrada em (a), zona de metalização com Ti no lado A.]

had been formed in a precipitation zone at the ceramic/filler interface (see side A in Fig. 10a and 10b) reliable vacuum tight joints were produced any way. Titanium from the coating reacted with both zirconium oxide from the zirconia ceramic and with the melted $\mathrm{Au}-18 \mathrm{Ni}$ filler to produce intermetallics in a precipitation zone. Probably a dark and very thin reaction layer was formed at the ceramic/filler interfaces (not noticeable with this magnitude) and less thick than that mentioned when used the eutectic $\mathrm{Ag}-\mathrm{Cu}$ filler. This precipitation zone is basically composed by Ti diluted by the melted filler alloy from its coating on the ceramic surface and Ti-Au compounds (see results exhibited in Fig. 11). The Au-Ti binary system is characterized by a series of well-established compounds, such as $\mathrm{Ti}_{3} \mathrm{Au}, \mathrm{TiAu}_{2}, \mathrm{TiAu} 4$ and $\alpha, \beta$ and $\gamma$-TiAu [11].

Scanning electron image plus respective EDX graphics for elemental $\mathrm{Ti}, \mathrm{Zr}, \mathrm{Au}$ and $\mathrm{Ni}$ by linescan technique through a selected region at the interface previously showed in Fig. 10b are shown in Fig. 11. According to the results, 

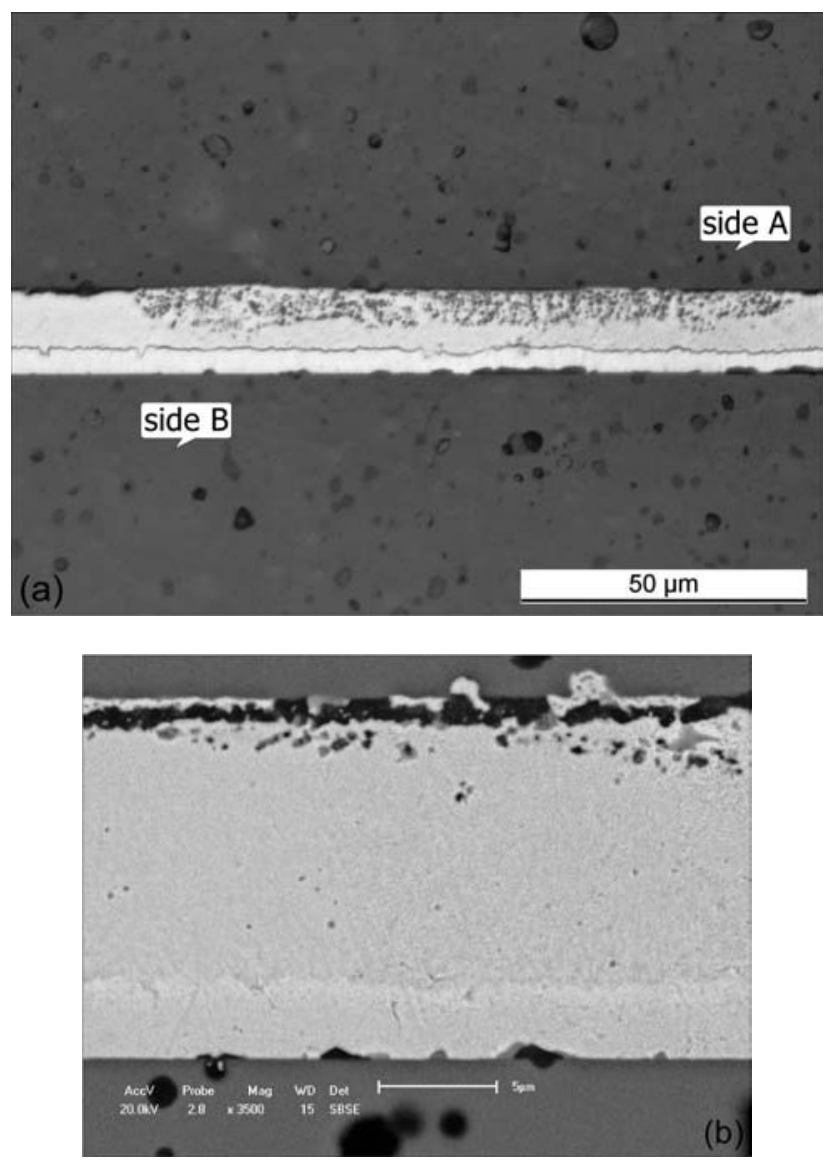

Figure 10: (a) Optical micrograph of Y-PSZ/Au-18Ni/Y-PSZ; (b) SEM image keeping the same positions A and B viewed in (a), metallization zone with $\mathrm{Ti}$ at the interface in side $\mathrm{A}$.

[Figura 10: (a) Micrografia óptica na interface da junta Y-PSZ/Au18Ni/Y-PSZ; (b) Imagem eletrônica mantendo as mesmas posições A e B vistas em (a), zona de metalização com Ti no lado A.]

the mechanical metallization with Ti was made in the side A of the ceramic substrate (see higher Ti EDX peaks at left) and there was Ti diffusion from the metallized surface across the bulk of melted filler alloy to the other ceramic side. It was noticed that there was also $\mathrm{Zr}$ difusion into depth melted filler at the braze region. Elements like titanium or zirconium reduce drastically the contact angle with the ceramic substrate and improve the ceramic/filler adhesion by reacting with the oxide that constitutes the main phase of the ceramic at the brazing temperature [4] - in this case, specifically with zirconium oxide (and probably some reaction with yttrium oxide).

Fig. 12 shows a schematic illustration about titanium diffusion corresponding to the Ti mechanical metallization in just one of the ceramic surfaces to be joined using activemetal-free filler alloy in the study. It was shown in previous Fig. $9 \mathrm{~b}$ and Fig. 11 that the brazing process was possible in these $\mathrm{ZrO}_{2} / \mathrm{ZrO}_{2}$ joints because there was Ti diffusion from the metallized surface to the other ceramic surface in contact. In fact, the Ti diffusion happened into depth its properly ceramic surface where Ti-coating was deposited and to the other substrate ceramic during brazing thermal cycle. It

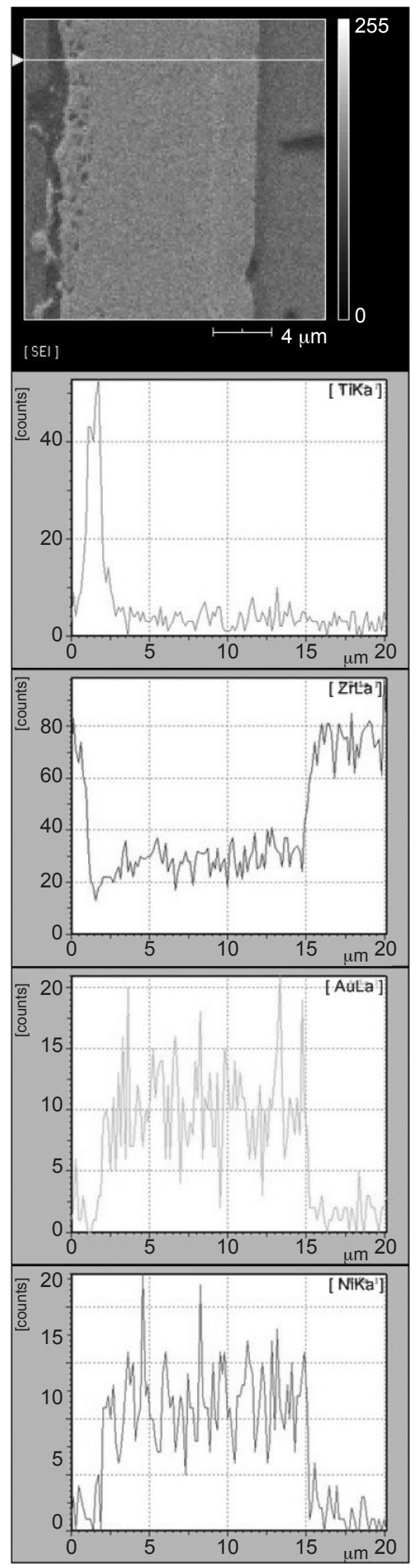

Figure 11: SEM image plus respective EDX graphics for elemental $\mathrm{Ti}, \mathrm{Zr}, \mathrm{Au}$ and $\mathrm{Ni}$ by linescan technique from a previous region viewed in Fig. $10 \mathrm{~b}$.

[Figura 11: Imagem eletrônica e gráficos EDX respectivos para os elementos $\mathrm{Ti}, \mathrm{Zr}$, Au e Ni pela técnica linescan na região vista na Fig. 10b.] 


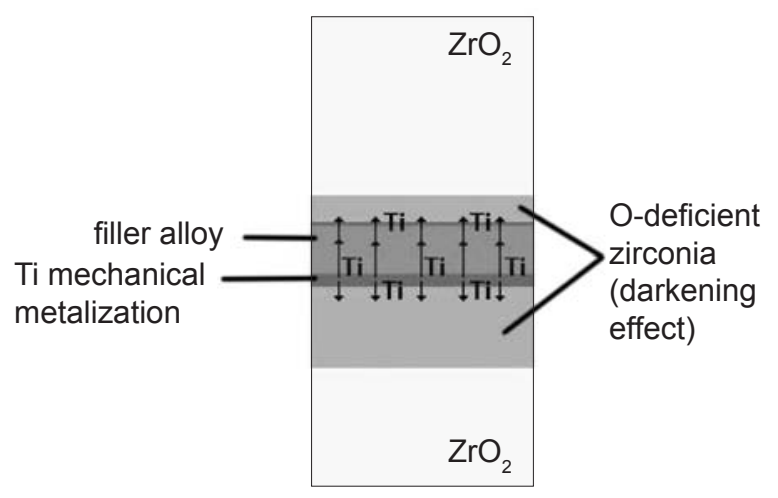

Figure 12: Schematic illustration of the Ti diffusion from the metallized ceramic surface.

[Figura 12: Ilustração esquemática da difusão de Ti a partir da superfície cerâmica metalizada.]

\section{Oxygen (atomic \%)}

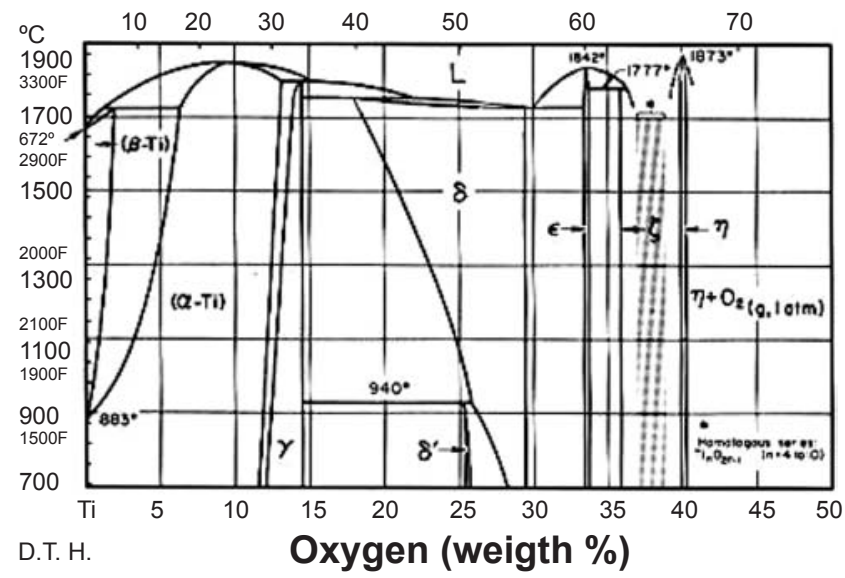

Figure 13: Ti-O phase equilibrium diagram [18].

[Figura 13: Diagrama de equilíbrio de fases para o sistema Ti-O [18].]

Table IV - Possible chemical reactions between Ti and zirconia ceramic constituents; Gibb's free energy change exclusively for reactions between $\mathrm{ZrO}_{2}$ and $\mathrm{Ti}$ at $850{ }^{\circ} \mathrm{C}[3,6]$.

[Tabela IV-Reações químicas possíveis entre Ti e constituintes da zircônia; variação da energia livre de Gibbs exclusivamente para as reações entre $\mathrm{ZrO}_{2}$ e Ti a $\left.850^{\circ} \mathrm{C}[3,6].\right]$

\begin{tabular}{|c|c|c|}
\hline Reactions with $\mathrm{ZrO}_{2}$ & $\Delta \mathrm{G}(\mathrm{kJ} / \mathrm{mol})$ at $850{ }^{\circ} \mathrm{C}$ & Reactions with $\mathrm{Y}_{2} \mathrm{O}_{3}$ \\
\hline $\mathrm{ZrO}+2 \mathrm{Ti} \rightarrow \mathrm{Zr}+2 \mathrm{TiO}$ & $+14,7$ & $\mathrm{Y}_{2} \mathrm{O}_{3}+2 \mathrm{Ti} \rightarrow \mathrm{Ti}_{2} \mathrm{O}_{3}+2 \mathrm{Y}$ \\
\hline $\mathrm{ZrO}_{2}+(4 / 3) \mathrm{Ti} \rightarrow \mathrm{Zr}+(2 / 3) \mathrm{Ti}_{2} \mathrm{O}_{3}$ & $+79,7$ & $\mathrm{Y}_{2} \mathrm{O}_{3}+(9 / 5) \mathrm{Ti} \rightarrow(3 / 5) \mathrm{Ti}_{3} \mathrm{O}_{5}+2 \mathrm{Y}$ \\
\hline $\mathrm{ZrO}_{2}+(6 / 5) \mathrm{Ti} \rightarrow \mathrm{Zr}+(2 / 5) \mathrm{Ti}_{3} \mathrm{O}_{5}$ & $+102,6$ & $\mathrm{Y}_{2} \mathrm{O}_{3}+(12 / 7) \mathrm{Ti} \rightarrow(3 / 7) \mathrm{Ti} 4 \mathrm{O}+2 \mathrm{Y}$ \\
\hline $\mathrm{ZrO}_{2}+(8 / 7) \mathrm{Ti} \rightarrow \mathrm{Zr}+(2 / 7) \mathrm{Ti}_{4} \mathrm{O} 7$ & $+113,9$ & $\mathrm{Y}_{2} \mathrm{O}_{3}+(3 / 2) \mathrm{Ti} \rightarrow(3 / 2) \mathrm{TiO}_{2}+2 \mathrm{Y}$ \\
\hline $\mathrm{ZrO}_{2}+\mathrm{Ti} \rightarrow \mathrm{Zr}+\mathrm{TiO}_{2}$ & $+145,1$ & $\mathrm{Y}_{2} \mathrm{O}_{3}+3 \mathrm{Ti} \rightarrow 3 \mathrm{TiO}+2 \mathrm{Y}$ \\
\hline
\end{tabular}

was visually noticed that it happened with more intensity for the former than the second mentioned situation. Because it was basically formed a longer dark area (O-deficient zirconia) from the brazed joint interface into depth zirconia, specifically where Ti-coating had been mechanically deposited before. Moreover, it is also important to remember that the melted filler alloy became active with Ti diffusion even there were poor local availability of this active metal in some defect areas of the Ti-coating [10].

Thermodynamic considerations - a short overview.

Interfacial interactions between the individual components to be joined should be considered in the study. Possible reactions involving zirconium oxide $\left(\mathrm{ZrO}_{2}\right)$ and yttrium oxide $\left(\mathrm{Y}_{2} \mathrm{O}_{3}\right)$ from zirconia ceramic and elemental titanium (in this case from the metallic coating) are summarized in Table IV with their corresponding values of Gibb's free energy change, $\Delta \mathrm{G}$, in the brazing temperature at $850{ }^{\circ} \mathrm{C}$. Titanium is considered an effective active metal to enhance ceramicmetal wettability by inducing chemical reactions during brazing temperature; moreover, titanium exhibits a strong thermodynamic affinity toward oxygen [3-6].
The positive $\Delta \mathrm{G}$ values (per mole of $\mathrm{ZrO}_{2}$ and $\mathrm{Y}_{2} \mathrm{O}_{3}$ ) shown in Table II predict that formation of titanium oxides by a simple direct reduction of zirconium and yttrium oxides is not thermodynamically favorable at $850{ }^{\circ} \mathrm{C}$. However, it might be possible to form these oxides from the reaction of Ti with the residual oxygen in the brazing furnace atmosphere, if not from the direct chemical reduction of the $\mathrm{ZrO}_{2}$ and $\mathrm{Y}_{2} \mathrm{O}_{3}$ constituents on the zirconia ceramic surface. It means a few atomic levels into the depth of the ceramic surface, which can have some influence in the $\Delta \mathrm{G}$ values calculation for these oxides. It is also believed that stable Ti oxides can be formed at even as low an oxygen partial pressure as $\mathrm{pO}_{2} \approx$ 10-28 atm [6]. Researchers have already proposed that Ti can act as an oxygen getter from the zirconia, which change its stoichiometry by producing an O-deficient ceramic area at the brazed joint interface and, thus these free oxygen atoms will be able to produce titanium oxides because the $\Delta \mathrm{G}$ values for the Ti oxide formation are negative at the brazing temperature for calculations in the range $750-850{ }^{\circ} \mathrm{C}[3,5,15]$. For instance, considering the oxidation behavior of Ticusil filler $(68.8 \mathrm{Ag}$ 26.7Cu-4.5Ti), the Gibb's free energy values of $\mathrm{Ti}$ oxides formation at $750{ }^{\circ} \mathrm{C}$ are (in $\left.\mathrm{kJ}\right)$ : $\mathrm{TiO}(-444.1), \mathrm{TiO}_{2},(-758.4)$, $\mathrm{Ti}_{3} \mathrm{O}_{5}(-2000.9)$ and $\mathrm{Ti} 4 \mathrm{O} 7$ (2764.4) [15]. These negative $\Delta \mathrm{G}$ 
values confirm the possibility to form titanium oxides.

In addition, according to the Ti-O phase diagram in Fig. 13 it is energetically favorable for $\alpha$-Ti phase to dissolve up to 34 at.\% oxygen; as the brazing temperature increases, the oxygen amount capable of going into solid solution also increases. It is also claimed that simple diffusion arguments based on Arrhenius-type equations can help to explain the zirconia reduction using titanium as the active metal [3].

\section{CONCLUSIONS}

Zirconia was mechanically metallized with titanium in just one ceramic side that was in contact at the interface and sound brazed ceramic/ceramic joints were successfully obtained using active-metal-free filler alloys. Satisfactory results were based on helium gas leak detection at the joints interface and conventional microestructural analysis. Conclusions below should be pointed out:

- Better results for wetting tests were obtained at $820{ }^{\circ} \mathrm{C}$ and $980{ }^{\circ} \mathrm{C}$ for the eutectic $\mathrm{Ag}-28 \mathrm{Cu}$ filler and the $\mathrm{Au}-18 \mathrm{Ni}$ filler, respectively.

- Helium gas leak tests for $\mathrm{ZrO}_{2} / \mathrm{Ag}-28 \mathrm{Cu} / \mathrm{ZrO}_{2}$ joints were bellow $10^{-9}$ mbar.l. $\mathrm{s}^{-1}$, which characterize reliable vacuum tight components. Leak rates for brazed $\mathrm{ZrO}_{2} / \mathrm{Au}-18 \mathrm{Ni} / \mathrm{ZrO}_{2}$ joints were also bellow $10^{-9} \mathrm{mbar} . \mathrm{s} \mathrm{s}^{-1}$.

- The darkening effect in zirconia at the joint interface was influenced by Ti (active metal) mechanically deposited and by the brazing thermal cycle.

- Interfacial microstructure in the braze region is relatively homogenous and characterized by the eutectic $\mathrm{Ag}-\mathrm{Cu}$ and $\mathrm{Au}-\mathrm{Ni}$ constituents depending on the filler, including a thin dark reaction layer (Ti-O compounds) closely to the ceramic/ filler interfaces. Intermetallic phases were produced in a precipitation zone closely to the mechanically deposited Ticoating on the ceramic surface, when it was used the $\mathrm{Au} 18 \mathrm{Ni}$ filler.

- There was chemical interdiffusion during brazing tests, which probably led to compositional changes across the joint interface - especially for Ti from the metallized substrate through the braze region to the other ceramic surface to be joined.

- Microhardness measurements were taken from the joint interface into depth zirconia along the darkening region and there was no measurable negative effect in this mechanical property.

\section{ACKNOWLEDGEMENTS}

The authors would like to thank the Forschungszentrum
Juelich team in Germany for their partnership and technical assistance in the study. J. S. Pimenta acknowledges the Capes-BR/DAAD PROBRAL Project for this international cooperation research and the CNPq agency for granting his doctorate scholarship in Brazil.

\section{REFERENCES}

[1] G. W. Liu, W. Li, G. J. Qiao, H. J. Wang, J. F. Yang, T. J. Lu, J. Alloys Compd. 470 (2009) 163.

[2] H. Q. Hao, Y. L. Wang, Z. H. Jin, X. T. Wang, J. Mater. Proc. Technol. 52 (1995) 238.

[3] W. B. Hanson, K. I. Ironside, J. A. Fernie, Acta Mater. 48 (2000) 4673.

[4] D. Sciti, A. Bellosi, L. Espósito, J. Eur. Ceram. Soc. 21 (2001) 45 .

[5] M. L. Muolo, E. Ferrera, L. Morbelli, Scripta Mater. 50 (2004) 325 .

[6] M. Singh, T. P. Shpargel, R. Asthana, Int. J. Appl. Ceram. Technol. 4, 2 (2007) 119.

[7] A. K. Jadoon, J. Mater. Sci. 39 (2004) 593.

[8] Q. Smorygo, J. S. Kim, M. D. Kim, T. G. Eom, Mater. Lett. 61 (2007) 613.

[9] R. M. Nascimento, A. E. Martinelli, A. J. A. Buschinelli, Cerâmica 49, 312 (2003) 178.

[10] R. M. Nascimento,A.J.A. Buschinelli, A. E. Martinelli, E. Sigismund, J. Remmel, U. Reisgen, E. Lugscheider, in 6th Int. Conf. Joining Ceramic, Glass and Metal, Munich, Germany (2002) 58.

[11] R. M. Nascimento, A.E. Martinelli,A. J.A. Buschinelli, E. Sigismund, Mater. Sci. Eng. A 466 (2007) 195.

[12] G. Elssner, G. Petzow, ISIJ Int. 30, 2 (1990) 1011.

[13] J. R. Kelly, I. Denry, Dental Mater. 24 (2008) 289.

[14] N. Yoshikawa, A. Kikuchi, S. Taniguchi, J. Mater. Sci. 34 (1999) 5885.

[15] M. Singh, T. P. Shpargel, R. Asthana, J. Mater. Sci. 43, 1 (2008) 23.

[16] O. M. Akselsen, J. Mater. Sci. 27 (1992) 1989.

[17] G. Schröder, J. C. P. Filho, W. Schmidt, Fundamentos de Ensaio de Vazamento e Estanqueidade, Reihe Allgemeines/ General, Band 1 - Forschungszentrum Jülich GmbH, Jülich, Germany (2000) 38 .

[18] Infomet, http://www.infomet.com.br/diagramas_fases. php, accessed 25 May 2009

[19] K. S. Weil, J. Y. Kim, J. S. Hardy, J. T. Darsell, Scripta Mater. 54 (2006) 1071.

[20] F. Löffler, Surface \& Coatings Technol. 132 (2000) 222.

(Rec. 28/06/2009, Ac. 28/08/2009) 